\title{
Methods assessment of self-tanning of rapeseed and sunflower meal fractions enriched in proteins and phenolic compounds using in vitro measurement of protein rumen degradability it the
}

\author{
Laurent-Philippe Broudiscou ${ }^{1, *}$, Oscar Laguna $^{2}$, Jérôme Lecomte ${ }^{2}$, Véronique Solé-Jamault ${ }^{3}$ \\ and Sylvie Dauguet ${ }^{4}$ \\ ${ }^{1}$ UMR MoSAR, AgroParisTech INRA, 75005 Paris, France \\ 2 CIRAD, UMR IATE, 34398 Montpellier, France \\ 3 BIA, INRA, 44300 Nantes, France \\ 4 Terres Inovia, 33318 Pessac, France
}

Received 28 October 2019 - Accepted 2 December 2019

\begin{abstract}
Two protein tanning methods were evaluated to contribute to the withdrawal of formaldehyde as a tanning agent of meals for feeding ruminants. The experimental materials were two fractions of rapeseed and sunflower meals collected at the positive electrode of an electrostatic separator, presenting high contents in proteins and phenolic compounds. The objective was to make phenolics and proteins interact without addition of exogenous tannins. Treatment $\mathrm{CH}$ incubated a meal fraction:water mixture $(1: 2, \mathrm{w}: \mathrm{w})$ for $48 \mathrm{~h}$ at $50^{\circ} \mathrm{C}$. Treatment FR incubated a meal fraction:water mixture $(1: 10, \mathrm{w}: \mathrm{w})$ at $\mathrm{pH} 9.0$ for $48 \mathrm{~h}$ at $4^{\circ} \mathrm{C}$. Microbial proteolysis on meal fractions were quantified during $24 \mathrm{~h}$ rumen batch fermentations with cellulose and starch as nitrogen-free energy sources. The net production of ammonia tended to be reduced by treatment FR mostly on rapeseed, corresponding to an $8 \%$ saving of rapeseed meal proteins degradable in the rumen. When untreated, the sunflower fraction decreased methane production by $50 \%$, while treatments restored the fermentation pattern. Cold alkaline treatment could be considered to protect meal proteins from degradation by rumen micro-organisms.
\end{abstract}

Keywords: rapeseed meal / sunflower meal / self-tanning / ruminant

\begin{abstract}
Résumé - Évaluation de deux méthodes d'auto-tannage de fractions de tourteaux de tournesol et de colza enrichies en protéines et composés phénoliques par mesure de la dégradabilité ruminale des protéines in vitro. Deux méthodes de tannage des protéines ont été évaluées pour contribuer au remplacement du formaldéhyde comme agent tannant des tourteaux destinés à l'alimentation des ruminants. Les matériaux expérimentaux étaient deux fractions de tourteaux de colza et tournesol collectées à l'électrode positive d'un séparateur électrostatique, présentant des teneurs élevées en protéines et en composés phénoliques. Le but était de faire interagir les composés phénoliques et les protéines sans addition de tanins exogènes. Le traitement $\mathrm{CH}$ a consisté à incuber un mélange tourteau/eau $\left(1 / 2\right.$, poids/poids) pendant $48 \mathrm{~h}$ à $50^{\circ} \mathrm{C}$. Le traitement $\mathrm{FR}$ a consisté à incuber un mélange tourteau/eau $\left(1 / 10\right.$, poids/poids) à $\mathrm{pH} 9,0$ pendant $48 \mathrm{~h}$ à $4^{\circ} \mathrm{C}$. La protéolyse des fractions de tourteau par les microbes du rumen a été quantifiée lors de fermentations in vitro de $24 \mathrm{~h}$ avec de la cellulose et de l'amidon comme sources d'énergie sans azote. Le traitement FR a eu tendance à réduire la production nette d'ammoniac, principalement avec le colza, équivalant à la protection de $8 \%$ des protéines de tourteau de colza dégradables dans le rumen. La fraction de tournesol non traitée a diminué la production de méthane de $50 \%$, cependant les traitements ont restauré le profil fermentaire. Le traitement alcalin à froid pourrait être envisagé afin de protéger les protéines du tourteau de la dégradation par les micro-organismes du rumen (the full text is available in French on https://www.ocl-journal.org/10.1051/ocl/2019051/olm).
\end{abstract}

Mots clés : tourteau de tournesol / tourteau de colza / auto-tannage / ruminant

\footnotetext{
${ }^{\text {tr }}$ Contribution to the Topical Issue "Technological challenges in Oilseed crushing and refining / Défis technologiques de la trituration et du raffinage des oléagineux"

सै The French version is available in "Supplementary Material".

*Correspondence: laurent.broudiscou@agroparistech.fr
} 


\section{Introduction}

Among the sources of dietary amino acids available to ruminants in Europe, rapeseed and sunflower cakes have been promoted for 50 years as alternatives to imported soybean meal (Grenet and Demarquilly, 1970; Richardson et al., 1981). However, regardless of the origin of the meal, reducing the degradation of their proteins by rumen microorganisms has been a constant concern for nutritionists. Indeed, rumen deamination of amino acids is nutritionally disadvantageous to the animal. It is only partly offset by de novo synthesis of microbial protein and results in a partial loss of ammonia by excretion of urea. The lowering of the rumen degradability of proteins, initially obtained also by toasting (Grenet and Demarquilly, 1970), mainly uses tanning with formaldehyde, which reacts with about ten amino acids, mainly asparagine, glutamine, lysine and arginine, to form methylene bonds that cause protein reticulation (Barry, 1976; Verite et al., 1977; Antoniewicz et al., 1992). These bonds are then hydrolysed when transiting from the rumen content at neutral $\mathrm{pH}$ to the abomasum acid medium. Although this industrial process was considered safe for the animal because the free formaldehyde fraction is rapidly metabolised in the rumen to carbon dioxide (Puigserver et al., 2004), growing social demand for more natural farming practices and the risks associated with the handling of formaldehyde during tanning have prompted the search for tanning agents of plant origin, in the continuity of pioneering work on chestnut wood hydrolysable tannins (Zelter et al., 1970). Among the secondary metabolites tested, the phenolic compounds present in the rapeseed peel and meal have been studied for their action on rumen microbial metabolism and their ability to interact with proteins (Wischer et al., 2013). However, the tanning power of rapeseed phenolic compounds is still poorly documented.

In addition, other ways of valorising rapeseed and sunflower meals, in particular as potential sources of bioactive molecules, have been studied (Hernandez-Jabalera et al., 2015). Recently Laguna et al. (2018) evaluated several dry separation techniques on their ability to isolate proteinenriched or phenolic-enriched meal fractions in advance of more selective processes. They established that electrostatic separation made it possible to collect on the positive electrode fractions with protein and phenolic contents higher than in initial cakes by $50-55 \%$ and $80-100 \%$ for rapeseed and sunflower respectively. In fact, these fractions are suitable materials for studying proteins tanning ability using endogenous phenolic compounds. Indeed, using this potential selftanning property of meals would limit the amounts of tannic extracts used during tanning or directly incorporated into the diet of ruminants.

Lowering the degradability of proteins by tannins involves various modes of interaction either covalent or non-covalent (Chu et al., 2018). According to Hernandez-Jabalera et al. (2015), the hydrolysable tannins present in rapeseed meal can complex with proteins by reversible hydrogen bonds. The common tanning treatment consists of mixing the meal with at least twice its weight of water, keeping the mixture for at least 20 hours at room temperature or in an oven and drying it at a temperature not exceeding $80^{\circ} \mathrm{C}$ (Zelter et al., 1970). However, a second way of cold and alkaline tanning could exist. Recently, (Bongartz et al., 2018) have shown that the alkaline treatment of sunflower meal induces the formation of chlorogenic acid quinones which react with the proteins of the meal. This phenomenon leads to the reduction of the simulated degradation of proteins by rumen microorganisms. Thus, the alkaline treatment increased rumen undegraded crude protein (RUP) values by factors ranging from about $3(\mathrm{Kp}=0.08 / \mathrm{h})$ to $12(\mathrm{Kp}=0.02 / \mathrm{h})$. Similar results were obtained in the laboratory (V. Solé-Jamault, personal communication). By subjecting the fraction of sunflower meal collected at the positive electrode to an extraction at $\mathrm{pH} 9$ for $48 \mathrm{~h}$, a crosslinking phenomenon was observed on electrophoresis gels suggesting a tanning of proteins.

Our study aims at quantifying the impact of two pretreatments - hot or cold and alkaline - on the rumen degradability of proteins in rapeseed and sunflower meal fractions enriched in proteins and phenolic compounds. An in vitro method makes it possible to attribute the variations in ammonia production to the deamination of the amino acids present in the meals fractions. The results were partially displayed as a poster at the International Rapeseed Congress held in Berlin in 2019.

\section{Material and methods}

\subsection{Treatments of meal fractions}

The self-tanning test was carried out on rapeseed and sunflower meal fractions harvested on the positive electrode of an electrostatic separator (TEP System, Tribo Flow Separations, Lexington, USA) and consisted of two steps, one pre-tanning, according to two methods described below, and an evaluation of this tanning by incubation in presence of rumen microbiota. The operating conditions of the electrostatic separation and the chemical composition of the two fractions are described by Laguna et al. (2018). Each fraction was divided into 3 batches: control (CT), cold pretreatment (CO) and heat pretreatment ( $\mathrm{HO})$. The $\mathrm{CO}$ pretreatment was a minimum $48 \mathrm{~h}$ maturation at $4{ }^{\circ} \mathrm{C}$ and $\mathrm{pH} 9.0$ (by adding $\mathrm{NaOH})$ in a closed container. The pretreatment $\mathrm{HO}$ was the mixture of the cake fraction with deionized water $(1: 2, \mathrm{w}: \mathrm{w})$ followed by a maturation for at least $48 \mathrm{~h}$ at $50^{\circ} \mathrm{C}$ in a closed container. The fractions were then freeze-dried.

\subsection{Incubations}

Three dry goats fitted with a rumen cannula provided the rumen content used as inoculum. They were housed in strawbedded group pen in an approved experimental facility (no. B78-615-1002). They were fed a diet made of hay, barley, mineral and vitamin supplement in two meals a day. The experimental procedures were approved by the local Ethics Committee (COMETHEA approval number 12079) agreed by the French Ministry of Higher Education and Research (agreement code C2EA-45) and they were performed on animals by accredited personnel. The rumen contents collected $(300 \mathrm{~mL}$ per animal) were immediately filtered through a $120 \mu \mathrm{m}$ mesh nylon gauze and brought to the laboratory under a $\mathrm{CO}_{2}$ atmosphere and in isothermal containers maintained at $37-40^{\circ} \mathrm{C}$. Three independent incubation series were done, each using the rumen contents of a given goat. In each series, incubations were made in 
duplicate in $72 \mathrm{~mL}$ culture tubes containing $60 \mathrm{mg}$ of cellulose, $40 \mathrm{mg}$ of starch and $50 \mathrm{mg}$ of one out of the three meal fractions (CT, $\mathrm{CO}$ or $\mathrm{HO}$ ) along with 2 incubations containing no experimental substrate and called "blanks" in order to quantify the fermentation products of the substrates present in unknown amounts in the inoculum. Each culture tube was filled with $10 \mathrm{~mL}$ Simplex buffer solution at $\mathrm{pH} 6.7 \pm 0.05$ (Broudiscou and Lassalas, 2000), with $6 \mathrm{~mL}$ inoculum, flushed with $\mathrm{CO}_{2}$ for $4 \mathrm{~min}$ to purge the head space from oxygen, tightly sealed and kept in a agitating water bath at $39^{\circ} \mathrm{C}$. Within each series, the culture tubes were randomly processed. Incubations were stopped $24 \mathrm{~h}( \pm 5 \mathrm{~min})$ later by cooling each tube at $+4{ }^{\circ} \mathrm{C}$ for at least $30 \mathrm{~min}$ before any measurement or sampling was undertaken. Then the tube was processed as follows. The amount and composition of fermentation gases were immediately measured, then the fermentation broth $\mathrm{pH}$ was measured and the culture medium was sampled $(1.2 \mathrm{~mL}$ stabilised with $0.3 \mathrm{~mL}$ ortho-phosphoric acid $25 \% \mathrm{v} / \mathrm{v}$, in duplicate) to quantify the concentrations of short-chain fatty acids (SCFA) and ammonia. The samples were immediately stored at $-21^{\circ} \mathrm{C}$ until analysis. The inoculums were sampled following the same procedure to quantify their SCFA concentrations.

\subsection{Analyses}

Ammonia concentration in culture media and inocula was measured using a specific electrode (Broudiscou and Papon, 1994). In centrifuged culture media and inocula (10 min at $10000 \mathrm{~g})$, SCFA were separated by reverse-phase HPLC $(4.6 \times 150 \mathrm{~mm}, 3 \mu \mathrm{m} \mathrm{C} 18$ ultra-aqueous column, acetonitrile-phosphate buffer $50 \mathrm{mM} \mathrm{pH} 2.0$ gradient) and their concentrations were quantified by spectrophotometry with a diode array detector ( $\lambda 210 \mathrm{~nm}$, Jasco, Lisses France). The fermentation gases composition was measured by GC (Varian, MicroGC) (Broudiscou et al., 2014).

\subsection{Calculations and statistical analyses}

The individual productions of SCFA, gases and ammonia from the fermentation of a given experimental substrate and used thereafter were calculated by difference between the amounts measured at the end of incubation in the tube containing the experimental substrate and those in the "blanks" of the same series.

The amount of hexoses fermented per tube (HF) was calculated using the formula proposed by Demeyer and Van Nevel (1975):

$$
\mathrm{HF}=(\mathrm{PC} 2+\mathrm{PC} 3) / 2+\mathrm{PC} 4+\mathrm{PC} 5(\mu \text { moles } / \text { tube }),
$$

PC2, PC3, PC4 and PC5 being the amounts of acetate, propionate, butyrate and valerate produced per tube in $24 \mathrm{~h}$ respectively.

The specific production (PS) of each SCFA was calculated using the formula:

$$
\mathrm{PS}=100 \times \text { producedamount } / \mathrm{HF}(\mu \text { moles } / 100 \mu \text { moles } \mathrm{HF}) \text {. }
$$

For each meal, the variables were subjected to an analysis of variance using the GLM procedure of the SAS
9.1 software (SAS/STAT $\left.{ }^{\circledR}, 2000\right)$. The two means per pretreament were compared to the mean of controls using the Dunnett test. In order to limit the total first-order error to 0.05 for significant differences and 0.10 for trends, the significance and trend thresholds were set at $P<0.025$ and $P<0.05$.

\section{Results and discussion}

In rapeseed meal incubations (Tab. 1), the intensity of cellulose and starch fermentations, as measured by the HF variable, and their profile were normal, with a predominance of acetate production to the detriment of propionate and butyrate as well as an efficient methanogenesis which has strongly limited the presence of dihydrogen. No tanning method has changed, even in trend, the fermentative variables. Net productions of ammonia and isovalerate - produced by the decarboxylation of the carbon chains of leucine and isoleucine (Demeyer and Van Nevel, 1979) - were negative (Tab. 2), indicating that the fermentations associated with the experimental substrate induced an ammonia consumption by rumen microorganisms greater than its release by deamination. Cold pretreatment $(\mathrm{CO})$ tended to increase this difference, whereas pretreatment at $50{ }^{\circ} \mathrm{C}(\mathrm{HO})$ did not have any effect even in trend. The effect of pretreatment $\mathrm{CO}$ can be attributed to a lower degradation of rapeseed meal proteins, clearly a selftanning process, rather than a stimulation of microbial protein synthesis. Indeed, the final $\mathrm{pH}$ of the fermentation medium was greater than 6.0 and did not vary between treatments. ATP from fermentations was therefore used to provide the energy needed for microbial growth and not to maintain a neutral intracellular pH (Strobel and Russell, 1986). Our observations based on a biological test implementing rumen microbiota activity extend to rapeseed meal the conclusions of Bongartz et al. (2018) who measured by an enzymatic method a decrease in proteolysis in a $\mathrm{CO}$ treated sunflower meal.

In control incubations (CT) of sunflower meal (Tab. 3), the intensity of carbohydrate fermentations was normal. However, their profile has been characterized by reduced specific productions of acetate and methane, in favour of propionate and hydrogen disulfide, and accompanied by a slight accumulation of dihydrogen. The untreated sunflower fraction may have disrupted the metabolism of methanogenic archaea, this reduction of methanogenesis impacting the activity of cellulolytic and acetate-producing bacteria, via the regeneration of their NAD and NADP cofactors, which requires a low dihydrogen partial pressure. (Baldwin and Allison, 1983). In this context, the increase in specific productions of propionate and hydrogen disulfide can be interpreted as an alternative entrapment of dihydrogen. The polyunsaturated fatty acids contained in the sunflower seed - mainly linoleic acid - cannot be the cause of this decrease in methanogenesis because the meal subjected to electrostatic separation was previously delipidated to a final content of $2 \%$ DM (Laguna et al., 2018). The inhibitory constituents are probably phenolic compounds (Mueller-Harvey, 2006). Eleven phenolic compounds, among which chlorogenic acid whose antibacterial activity has been observed in pure cultures (Lou et al., 2011), were detected in the sunflower fraction (Laguna et al., 2018) but their effects on methanogenic archaea 
Table 1. Amount of hexoses fermented (HF) and specific productions of fermentation end-products from the experimental substrate containing the rapeseed meal fraction.

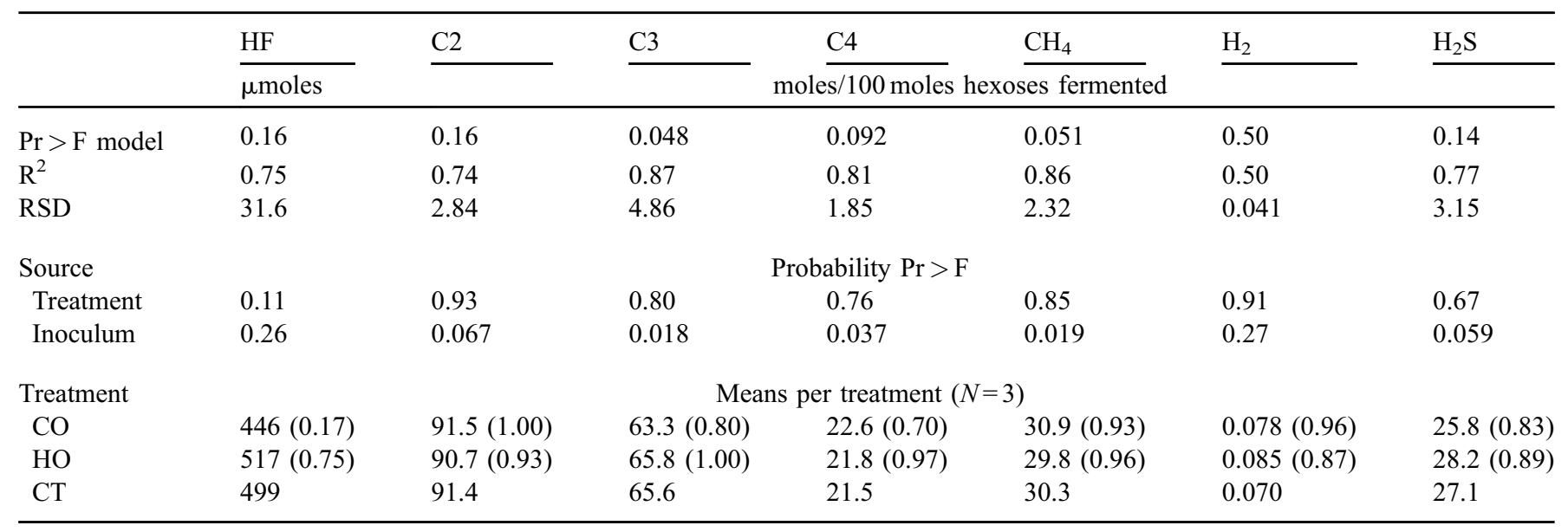

Table 2. Net productions of ammonia ( $\mathrm{mg} /$ tube) and isovalerate ( $\mu$ moles/tube) from the rapeseed fraction and culture medium final $\mathrm{pH}$.

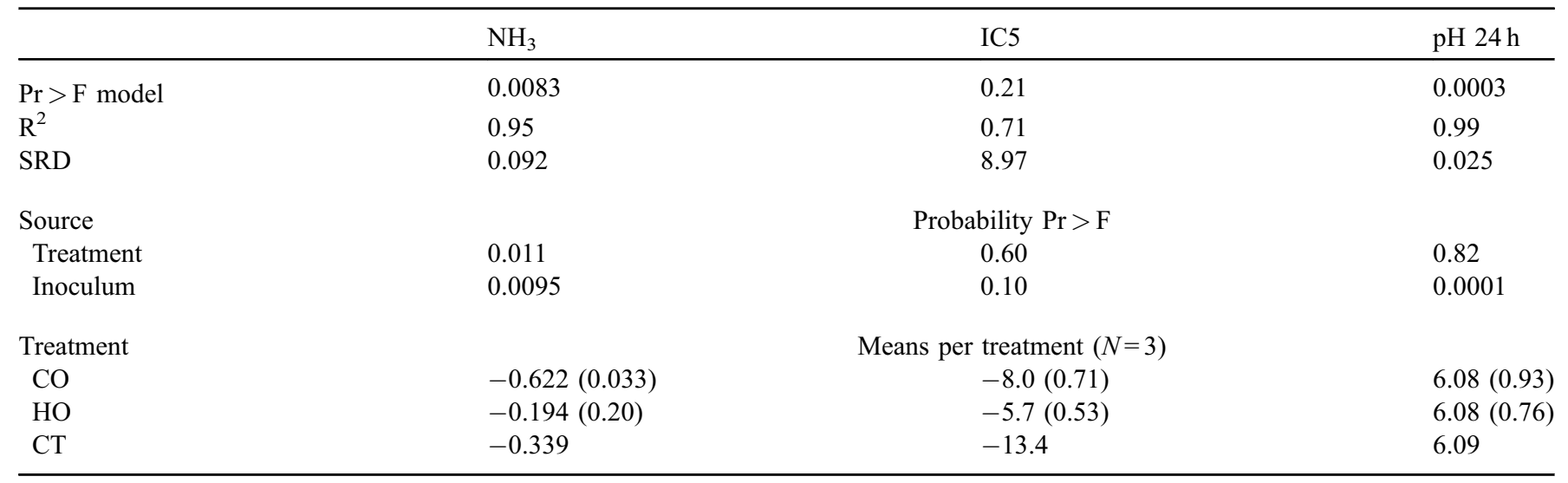

IC5: isovalerate; RSD: residual standard deviation; comparison of cold and hot pretreatments (CO and $\mathrm{HO})$ with control (CT): the first-order errors are in brackets.

Table 3. Amount of hexoses fermented (HF) and specific productions of fermentation end-products from the experimental substrate containing the sunflower meal fraction.

\begin{tabular}{|c|c|c|c|c|c|c|c|}
\hline & $\mathrm{HF}$ & $\mathrm{C} 2$ & $\mathrm{C} 3$ & $\mathrm{C} 4$ & $\mathrm{CH}_{4}$ & $\mathrm{H}_{2}$ & $\underline{\mathrm{H}_{2} \mathrm{~S}}$ \\
\hline $\operatorname{Pr}>\mathrm{F}$ model & 0.011 & 0.034 & 0.029 & 0.30 & 0.058 & 0.42 & 0.025 \\
\hline RSD & 14.8 & 4.36 & 4.10 & 1.59 & 5.57 & 0.91 & 10.2 \\
\hline Source & & & & ability $\operatorname{Pr}>F$ & & & \\
\hline Inoculum & 0.14 & 0.043 & 0.022 & 0.16 & 0.13 & 0.39 & 0.66 \\
\hline Treatment & & & Means & $\mathrm{r}$ treatment $(\Lambda$ & & & \\
\hline $\mathrm{CO}$ & $447(0.0088)$ & $89.1(0.055)$ & $64.1(0.093)$ & $23.4(0.58)$ & $31.0(0.033)$ & $0.10(0.37)$ & $19.5(0.0065)$ \\
\hline $\mathrm{HO}$ & $533(0.33)$ & $91.3(0.032)$ & $61.6(0.047)$ & $23.5(0.62)$ & $28.3(0.057)$ & $0.10(0.37)$ & $36.7(0.028)$ \\
\hline $\mathrm{CT}$ & 514 & 77.7 & 73.0 & 24.7 & 13.9 & 1.14 & 70.0 \\
\hline
\end{tabular}

$\mathrm{C} 2$ : acetate; $\mathrm{C} 3$ : propionate; $\mathrm{C} 4$ : butyrate; $\mathrm{SRD}$ : residual standard deviation; comparison of pretreatments $(\mathrm{CO}$ and $\mathrm{HO})$ with control $(\mathrm{CT})$ : the first order errors are in brackets. 
Table 4. Net productions of ammonia (mg/tube) and isovalerate ( $\mu$ moles/tube) from the sunflower fraction and culture medium final $\mathrm{pH}$.

\begin{tabular}{|c|c|c|c|}
\hline & $\mathrm{NH}_{3}$ & IC5 & $\mathrm{pH}$ \\
\hline $\mathrm{R}^{2}$ & 0.92 & 0.95 & 0.95 \\
\hline Source & & Probability $\operatorname{Pr}>F$ & \\
\hline Treatment & 0.020 & 0.072 & 0.26 \\
\hline Treatment & & Means per treatment $(N=3)$ & \\
\hline $\mathrm{CO}$ & $0.15(0.070)$ & $-14.8(0.064)$ & $6.16(0.51)$ \\
\hline $\mathrm{HO}$ & $0.88(0.20)$ & $-12.6(0.11)$ & $6.12(0.20)$ \\
\hline $\mathrm{CT}$ & 0.59 & -3.3 & 6.21 \\
\hline
\end{tabular}

IC5: isovalerate; RSD: residual standard deviation; comparison of cold and hot pretreatments (CO and HO) with control (CT): the first-order errors are in brackets.

are not documented. $\mathrm{CO}$ pre-treatment slightly reduced the intensity of fermentations. More surprisingly, both pretreatments restored the fermentation profiles, characterized by active methanogenesis and a low presence of dihydrogen and close to those observed with rapeseed meal, suggesting that they inactivated the component of the meal fraction responsible for the partial inhibition of methanogens.

No pretreatment significantly changed the net production of ammonia (Tab. 4) and isovalerate. The hierarchy between fractions, however, was similar to that observed with rapeseed meal, CO pretreatment being associated with the lowest ammonia production, in agreement with the results of Bongartz et al. (2018).

In conclusion, only the cold and alkaline pretreatment tended to reduce the microbial proteolysis of the meal fractions (mainly for rapeseed meal), in a proportion too small, however, to present a nutritional advantage for ruminants. In addition, methanogenesis was reduced in the presence of the untreated sunflower fraction, suggesting the inhibitory action of a phenolic compound still to be identified.

Acknowledgements. This work was performed, in partnership with the SAS PIVERT, within the frame of the French Institute for the Energy Transition (Institut pour la transition énergétique [ITE] P.I.V.E.R.T. [www.institut-pivert.com] selected as an Investment for the Future ["Investissements d'Avenir"]. This work was supported, as part of the Investments for the Future, by the French Government under the reference ANR-001-01.

Conflicts of interest. The authors declare that they have no conflicts of interest in relation to this article.

\section{Supplementary Material}

French version.

The Supplementary Material is available at https://www.ocljournal.org/10.1051/ocl/2019051/olm.

\section{References}

Antoniewicz AM, Vanvuuren AM, Vanderkoelen CJ, Kosmala I. 1992. Intestinal digestibility of rumen undegraded protein of formaldehyde-treated feedstuffs measured by mobile bag and in vitro technique. Anim Feed Sci Technol 39: 111-124.

Baldwin RL, Allison MJ. 1983. Rumen metabolism. J Anim Sci 57: 461-477.

Barry TN. 1976. Effectiveness of formaldehyde treatment in protecting dietary-protein from rumen microbial-degradation. Proc Nutr Soc 35: 221-229.

Bongartz V, Bottger C, Wilhelmy N, Schulze-Kaysers N, Sudekum $\mathrm{KH}$, Schieber A. 2018. Protection of protein from ruminal degradation by alkali-induced oxidation of chlorogenic acid in sunflower meal. J Anim Physiol Anim Nutr 102: E209-E215.

Broudiscou LP, Papon Y. 1994. Quantification of ammonia in rumen and fermenter fluid samples by a gas-sensing electrode. Reprod Nutr Dev 34: 193-200.

Broudiscou LP, Lassalas B. 2000. Effects of Lavandula officinalis and Equisetum arvense dry extracts and isoquercitrin on the fermentation of diets varying in forage contents by rumen microorganisms in batch culture. Reprod Nutr Dev 40: 431-440.

Broudiscou LP, Offner A, Sauvant D. 2014. Effects of inoculum source, $\mathrm{pH}$, redox potential and headspace di-hydrogen on rumen in vitro fermentation yields. Animal 8: 931-937.

Chu Q, Bao B, Wu W. 2018. Mechanism of interaction between phenolic compounds and proteins based on non-covalent and covalent interactions. Med Res 2(3): 180014.

Demeyer DI, Van Nevel CJ. 1975. Methanogenesis, an integrated part of carbohydrate fermentation and its control. In: McDonald IW, Warner ACI, eds. Digestion and metabolism in the ruminant. Armidale: University of New England Publishing Unit, pp. 366-382.

Demeyer D, Van Nevel C. 1979. Protein fermentation and growth by rumen microbes. Ann Rech Vet 10: 277-279.

Grenet N, Demarquilly C. 1970. Rapeseed oil-meal in animal feeding. 2. Study feeding value for ruminants, effect of processing method. Ann Zoot 19: 269-277.

Hernandez-Jabalera A, Cortes-Giraldo I, Davila-Ortiz G, et al. 2015. Influence of peptides-phenolics interaction on the antioxidant 
profile of protein hydrolysates from Brassica napus. Food Chem 178: $346-357$.

Laguna O, Barakat A, Alhamada H, et al. 2018. Production of proteins and phenolic compounds enriched fractions from rapeseed and sunflower meals by dry fractionation processes. Ind Crops Prod 118: 160-172.

Lou ZX, Wang HX, Zhu S, Ma CY, Wang ZP. 2011. Antibacterial activity and mechanism of action of chlorogenic acid. J Food Sci 76: M398-M403.

Mueller-Harvey I. 2006. Unravelling the conundrum of tannins in animal nutrition and health. J Sci Food Agric 86: 2010-2037.

Puigserver A, Andrieu JP, Bories G, Paragon BM, Warnet JM. 2004. Évaluation des risques liés à l'utilisation du formaldéhyde en alimentation animale. Maison-Alfort: AFSSA, p. 25.

Richardson CR, Beville RN, Ratcliff RK, Albin RC. 1981. Sunflower meal as a protein-supplement for growing ruminants. J Anim Sci 53: $557-563$.
Sas/Stat ${ }^{\circledR} .2000$. User's guide. Release 11.04. Cary: SAS Institute, Inc. Strobel HJ, Russell JB. 1986. Effect of pH and energy spilling on bacterial protein synthesis by carbohydrate-limited cultures of mixed rumen bacteria. J Dairy Sci 69: 2941-2947.

Verite R, Poncet C, Chabi S, Pion R. 1977. Utilization of formaldehyde treated oil-meals by dairy-cows. 1. Digestive aspects. Ann Zoot 26: 167-181.

Wischer G, Boguhn J, Steingass H, Schollenberger M, Rodehutscord M. 2013. Effects of different tannin-rich extracts and rapeseed tannin monomers on methane formation and microbial protein synthesis in vitro. Animal 7: 1796-1805.

Zelter SZ, Leroy F, Tissier JP. 1970. Protection of proteins in feed against bacterial deamination in rumen. 1. Studies in vitro - behaviour in rumen of some proteins tanned with tannin from chestnut wood or certain aldehydes (formaldehyde, glutaraldehyde, glyoxal). Ann Biol Anim Bioch Biophys 10: $111-122$

Cite this article as: Broudiscou L-P, Laguna O, Lecomte J, Solé-Jamault V, Dauguet S. 2020. Methods assessment of self-tanning of rapeseed and sunflower meal fractions enriched in proteins and phenolic compounds using in vitro measurement of protein rumen degradability. OCL 27: 1 . 